\title{
Does She Deserve It? The Influence of Gender and Meritocracy in Reactions to Affirmative Action Legislation
}

\author{
Virgínia Silva ${ }^{1}$, Maria Helena Santos ${ }^{1,2}, * \mathbb{D}$ and Miriam Rosa ${ }^{1,2}$ (D) \\ 1 Instituto Universitário de Lisboa (Iscte-IUL), 1649-026 Lisboa, Portugal; virginia_silva@iscte-iul.pt (V.S.); \\ miriam.rosa@iscte-iul.pt (M.R.) \\ 2 Instituto Universitário de Lisboa (Iscte-IUL), CIS-IUL, 1649-026 Lisboa, Portugal \\ * Correspondence: helena.santos@iscte-iul.pt
}

Citation: Silva, Virgínia, Maria Helena Santos, and Miriam Rosa 2021. Does She Deserve It? The Influence of Gender and Meritocracy in Reactions to Affirmative Action Legislation. Social Sciences 10: 386. https://doi.org/10.3390/ socsci10100386

Academic Editor: Lauren Dundes

Received: 23 August 2021

Accepted: 8 October 2021

Published: 13 October 2021

Publisher's Note: MDPI stays neutral with regard to jurisdictional claims in published maps and institutional affiliations.

Copyright: (c) 2021 by the authors. Licensee MDPI, Basel, Switzerland. This article is an open access article distributed under the terms and conditions of the Creative Commons Attribution (CC BY) license (https:// creativecommons.org/licenses/by/ $4.0 /)$.
Abstract: Gender equality is a matter for debate worldwide. In 2018, Portugal enacted legislation (Decree Law no. 62/2017) to balance gender representation on the executive boards of listed and public sector organizations with measures similar to those causing controversies in other countries. Thus, in accordance with previous research, a study took place to examine the attitudes towards the justice of this legislation and the role of merit in these attitudes. This study $(n=129$ women and 94 men) deployed an experimentally manipulative type of affirmative action program to consider the role of individual perceptions of the justice of the legislation coupled with the influence of beliefs in meritocracy and participant gender. The results identify how the type of affirmative action impacted on the perceived justice, also influenced by merit, which seems normative and fundamental to evaluating the justice of such legally stipulated provisions. Nonetheless, objectively evaluating candidate merits revealed difficulties in disentangling this process from personality traits.

Keywords: law number 62/2017; gender in/equality; affirmative action; meritocracy

\section{Introduction}

Although female participation in the labor market has increased (Amâncio and Santos 2021), their under-representation in management positions remains a present and transversal phenomenon in various organizations and societies (Acker 2009; Casaca and Lortie 2018; Castaño et al. 2019). The "glass ceiling" metaphor explains this through identifying the existence of "invisible" organizational obstacles that hinder women's access to the top positions in organizations. Some women come close to these positions, but those who do reach them are rare (Acker 2009; Casaca and Lortie 2018). One of the main root causes of this discrimination relates to traditional gender roles (Castaño et al. 2019). Men are attributed with innate capacities for leadership, results-orientation, competitiveness, strength, and sustenance. Women, on the other hand, are attributed with an innate predisposition for caregiving, with their main functions being caring for the family and household chores (Amâncio and Correia 2019; Casaca and Lortie 2018). The definition of adulthood associated with the female stereotype is limited to affective functions and being objects of desire and to a lack of any of the qualities oriented towards work and individual autonomy (Amâncio and Oliveira 2006). To combat these gender inequalities, affirmative action measures (AAMs) have been implemented in various sectors (Kravitz and Platania 1993). In general, AAMs are temporary and proactive policies (Lee 1999) that aim to eliminate and prevent discrimination based on group membership and to correct existing imbalances and the effects of past discrimination (Commission for Citizenship and Gender Equality 2015). In this sense, the objectives of this research are to understand the reactions of individuals to an AAM and to analyze what role meritocracy plays in these attitudes.

There are several types of AAMs (Aberson 2007): (i) race-blind policies, where all information about the candidate is omitted; (ii) recruitment and training policies, which 
focus both on attracting more diverse candidates and on training to improve the qualifications of potential candidates from minority groups; (iii) weak preferential treatment (PT) measures, which favor members of the minority group when they have similar or comparable competencies with other candidates; and (iv) strong PT measures, which include the selection of candidates on the basis of their group membership, regardless of their qualifications. The various types of AAMs can be organized along a continuum ranging from soft to hard: programs at the soft pole (e.g., race-blind policies) use individual merit as the main criterion in recruitment choices or promotion processes, while programs at the hard pole (e.g., strong PT) use group membership as the central criterion (Moscoso et al. 2012; Krings et al. 2007). The further one moves along the continuum, the less the importance attributed to individual merit and the greater the importance given to group membership. This research considers both weak and strong PT measures.

In Portugal, Law Number 62/2017 came into force, establishing a regime of "balanced representation between women and men in the management and supervisory bodies of corporate public sector entities and listed companies" (Law Number 62/2017 of 1 August 2017). This law, which is similar to the so-called "Parity Law" (Organic Law Number 3/2006 of 21 August, replaced by Organic Law number 1/2019 of 29 March 2019), was implemented in the context of these politics and makes it mandatory to include a $33.3 \%$ membership of each sex in new appointments to the management and supervisory bodies of public sector companies and those listed on the stock market.

AAMs of this type have already generated a great deal of controversy (Crosby et al. 2006; Harrison et al. 2006; Morgenroth and Ryan 2018; Santos and Amâncio 2010a), with positions for and against. AAM proponents claim that these measures (i) enable the rectification of past discrimination and prevent discrimination into the future; (ii) are necessary to ensure diversity in the labor market; and (iii) help ensure that selection processes and decisions are fairer (Crosby et al. 2006; Krings et al. 2007). In contrast, opponents argue that these measures are unfair because they attribute preferential treatment to one group, based on group membership, leading to violations of meritocracy (Crosby et al. 2006; Krings et al. 2007). Additionally, because they believe that gender and racial discrimination are no longer widespread problems, AAM opponents also do not perceive these measures as necessary (Crosby et al. 2006).

Attitudes towards AAMs vary according to the type of measure under analysis (softer or harder), and support for AAMs is inversely proportional to the weighting they attribute to group membership. Thus, people show greater support for softer measures (e.g., "raceblind" policies) and greater opposition to harder measures (e.g., weak PT; Kravitz and Platania 1993; Aberson 2007; Krings et al. 2007; Faniko et al. 2010; Taillandier-Schmitt and Maisonneuve 2019). One explanation for this pattern stems from how the hardest measures violate meritocracy (Davey et al. 1999; Krings et al. 2007; Harrison et al. 2006). Additionally, people display more positive attitudes towards AAMs when provided with justifications (Taylor-Carter et al. 1995; Harrison et al. 2006; Crosby et al. 2006). Justifying AAMs through the arguments that they remedy past discrimination or that such programs are necessary to increase diversity (Harrison et al. 2006), and emphasizing the economic advantages of a diverse work environment (Kravitz et al. 2008), returns a positive effect on reactions to AAMs. In contrast, justifying these programs by pointing out that the target group is numerically under-represented generates a negative effect (Harrison et al. 2006).

Attitudes towards AAMs also depend on the characteristics of the observer and/or target. Minorities, such as women, display more positive attitudes toward AAMs (Kravitz and Platania 1993; Harrison et al. 2006), possibly because they are themselves targets of discrimination, and majorities show more opposition, either because they believe that discrimination no longer constitutes a widespread problem (Kravitz et al. 2008) or because of racism/sexism (Kravitz 1995; Crosby et al. 2006; Harrison et al. 2006). The effects of these variables on attitudes towards AAMs become greater the further we move along the soft-hard continuum (Harrison et al. 2006). Moreover, the more people perceive that discrimination exists, the more they accept these measures (Harrison et al. 2006; Krings et al. 
2007; Aberson 2007). As regards political orientation, liberals tend to register more positive attitudes than conservatives (Harrison et al. 2006; Aberson 2007), and when measures are targeted at people with disabilities, they are better accepted than those targeted at ethnic minorities and/or women (Santos 2004; Kravitz and Platania 1993).

The perceived fairness of AAMs also provides a determinant: the more unfair the measures are perceived to be, the more negative the attitudes (Kravitz 1995; Taylor-Carter et al. 1995). The further along the soft-hard continuum we move, the greater the perception of the policies as unfair (Son Hing et al. 2002), as the harder measures may allow for the hiring of less competent people, violating the merit principle (Harrison et al. 2006; Krings et al. 2007; Son Hing et al. 2002).

Meritocracy is an ideology according to which equal opportunities exist and upward social mobility is enabled, with individuals gaining the opportunity to change their social and economic circumstances. Thus, the economic and social success a person achieves is determined by internal factors, such as hard work, skills, and responsibility, rather than by privileged social relationships. Thus, it is individual merit, not power or social category, that determines the success of each person (Major and Kaiser 2017).

Meritocracy is a norm with high support in Western culture (Son Hing et al. 2011; Madeira et al. 2019) as it serves as a principle of distributive justice (i.e., fairness in the distribution of resources; Davey et al. 1999) and maximizes individual outcomes (Mijs 2016). However, this also interlinks with beliefs, behaviors and practices that may help maintain the status quo and legitimize social inequality (Son Hing et al. 2011), blaming those who fail for their failure (Batruch et al. 2019).

As distributive justice, meritocracy leads to the non-acceptance of AAMs when group membership becomes one of the selection criteria as this may then allow for the hiring of a less qualified member when compared to his or her competitors. This may be deemed a violation of the merit principle (Harrison et al. 2006; Krings et al. 2007; Son Hing et al. 2002). In the organizational context, AAMs are perceived as fair when based on the merit principle (Pereira et al. 2012), increasing organizational citizenship behaviors (Chou et al. 2013) and decreasing turnover intentions (Rai et al. 2019).

As a legitimation of already-existing inequalities, the belief in meritocracy (a) predicts support for other hierarchy-legitimating ideologies (Jost and Hunyady 2005; Son Hing et al. 2011); (b) decreases support for the AAMs that challenge the status quo on behalf of the members of disadvantaged groups (Garcia et al. 2005; Son Hing et al. 2011); and (c) decreases self-esteem and increases the guilt that the members of disadvantaged groups feel for their group's situation (Madeira et al. 2019).

The means of ascertaining whether meritocracy is serving a principle of justice or legitimizing the system involves identifying how these beliefs are supported: in a descriptive (i.e., beliefs about how society operates) or a prescriptive way (i.e., beliefs about how the results should be distributed, Son Hing et al. 2011), with the descriptive meritocratic beliefs (MBs) being related to legitimizing the system and the prescriptive beliefs being more closely associated with fairness (Son Hing et al. 2011). In addition, people with stronger descriptive MBs report greater opposition to AAMs (Son Hing et al. 2011), independently of the type of program, whereas people with stronger prescriptive MBs express greater opposition to AAMs that violate the merit principle (Son Hing et al. 2011; Davey et al. 1999; Son Hing et al. 2002; Faniko et al. 2010).

\section{Our Research: Overview and Hypotheses}

This research derives from the Lorenzi-Cioldi and Buschini (Lorenzi-Cioldi and Buschini 2002) research on the business context and the Santos (Santos 2004) research focused on the political context. The main objective is to analyze the reactions to the justice arising out of Law Number 62/2017 as there is no existing research on this topic to the best of our knowledge. 
Given the controversy generated by AAMs and the centrality of merit in Western society (Son Hing et al. 2011; Madeira et al. 2019), this study aims to: (i) understand individual tolerance towards the justice of Law Number 62/2017 and (ii) analyze the influence of the type of AAMs (weak PT vs. strong PT), the type of belief in meritocracy, and the gender of the participant on attitudes towards the justice of Law Number 62/2017 (see Figure 1). To manipulate the AAM type, the four scenarios applied in the studies by Lorenzi-Cioldi and Buschini (Lorenzi-Cioldi and Buschini 2002) and Santos (Santos 2004) were used to characterize the preferential treatment. They were complemented with competences and characteristics associated with a managerial/leadership position, captured from Silva (2020, Study 1).

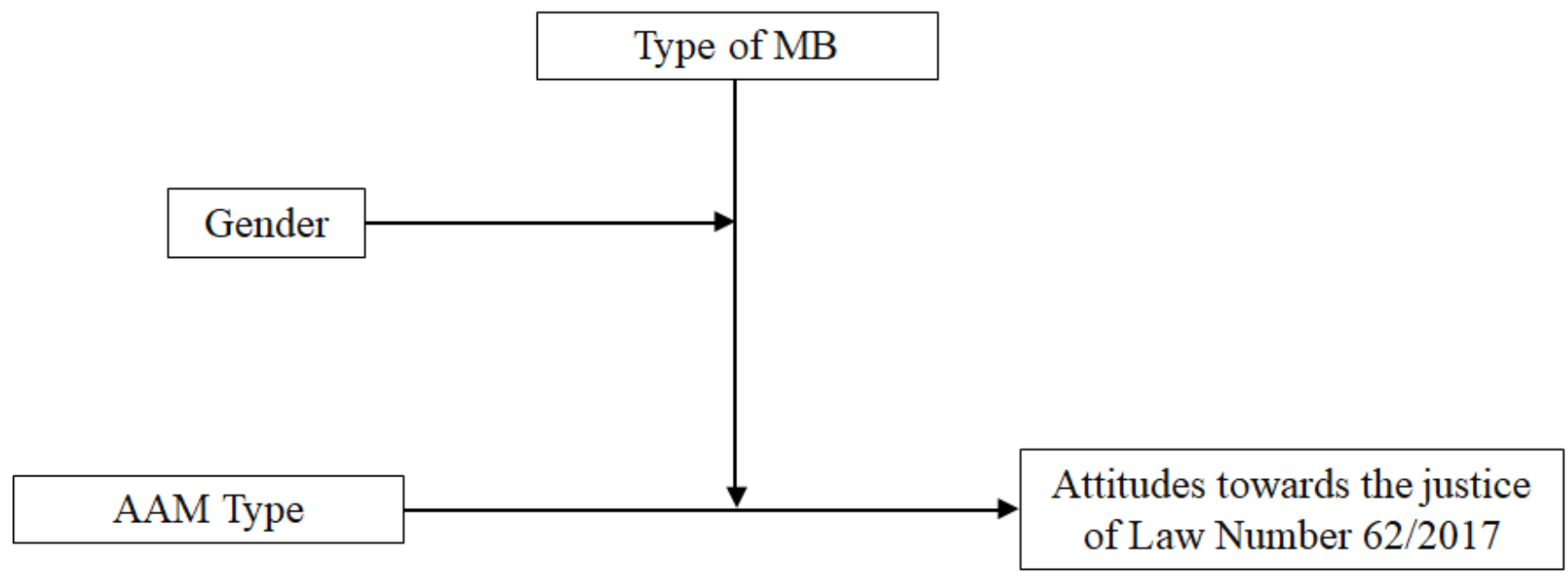

Figure 1. Research model proposed. MB-Meritocracy Beliefs; AAM-Affirmative Action Measure.

The hypotheses of this study are formulated in terms of the expectations that attitudes towards the justice of Law Number 62/2017 are more positive under weak PT conditions compared to strong PT conditions (H1); women generally report more positive attitudes towards the justice of the law than men (H2); regardless of the PT condition, descriptive meritocracy beliefs (MBs) lead to more negative attitudes towards the justice of this law (H3); under strong PT conditions, prescriptive MBs lead to more negative attitudes towards the justice of the same law (H4); and under weak PT conditions, prescriptive MBs lead to more positive attitudes towards the justice of the law for women compared to those for men (H5).

The study obtained ethical approval from the university.

\section{Method}

This study deploys a quasi-experimental between-subjects design: 4 (types of AAM: equality of competencies between the female candidate and the male candidate vs. the female candidate being more competent than the male candidate vs. the female candidate being less competent than the male candidate vs. the choice based on group membership) $\times 2$ (gender of participants: men vs. women).

\subsection{Participants}

A total of 223 individuals participated in this study, 129 women and 94 men, aged between 18 and 65 years $(M=27.20, S D=9.20)$. A narrow majority of the sample $(58.7 \%)$ was comprised of university students, and the most common academic qualification was "polytechnic or higher education" (78\%).

The questionnaire was disseminated through social networks and hence the sample was also of the convenience and "snowball" type. The only inclusion criterion was that the participants should be aged 18 or over. 


\subsection{Procedure}

After informed consent, we randomly presented participants with one of the four experimental scenarios followed by the dependent measures: attitudes towards the justice of the law, preference for the merit principle, and perceptions of the existence of meritocracy. The questionnaire ended with sociodemographic questions and the presentation of a debriefing.

The data collection process took place online through the Qualtrics Platform (Provo, UT) with an average duration of $10 \mathrm{~min}$. We analyzed the data by recourse to IBM SPSS Statistics 25 software (IBM Corporation, Armonk, New York) and the respective Macro PROCESS version 3.3 , created and documented by Hayes (2017).

\subsection{Experimental Manipulations}

The four experimental scenarios were adapted from the research studies of Santos (Santos 2004) and Lorenzi-Cioldi and Buschini (Lorenzi-Cioldi and Buschini 2002), and differed in the type of target AAM (weak PT or strong PT): here, the weak PT conditions included the scenarios in which there was an equality of competencies between the female candidate and the male candidate and in which the female candidate was more competent than the male candidate, along with strong PT conditions corresponding to the scenarios in which the female candidate was less competent than the male candidate and in which the choice was based on group membership. These scenarios, which assume the status of the moderator variable in the model under study, were the subject of a pre-test in research by Santos (2004) and, taking into account that the verification of this type of manipulation can amplify, undo, or interact with the effects of the manipulation (Hauser et al. 2018), we chose not to perform manipulation checks in this research study. The competencies obtained in Silva (2020, Study 1) were added to the four scenarios ("organized", "communicative", and "proactive"), characterized by two fictional characters, Julia and Antonio, who were running for the same management position. The scenarios are described below.

Scenario 1 "equality of competences between the female and male candidates": Julia and Antonio met at university where they both graduated in Business Management. All their colleagues considered them to be very organized, communicative, and proactive and even their teachers perceived them as very competent, responsible and team-oriented. Today, Julia and Antonio are two highly respected managers of large, listed companies, with reputations as entrepreneurial professionals with enormous knowledge, emotional intelligence, and leadership spirit. Recently, company $X$ was recruiting for a senior management position and they both decided to apply. However, in 2017, a law was enacted in Portugal (Law Number 62/2017 of 1 August 2017) establishing the "Regime of balanced representation between women and men in the management and supervisory bodies of the entities of the public business sector and listed companies" aiming to increase the presence of women in these positions. Company $X$, which is listed on the stock exchange, implemented this law and stipulated that, under conditions of equal competencies, preference should be given to women. As she has the same competencies as her competitor Antonio, Julia was chosen for the position.

Scenario 2 "female candidate more competent than male candidate": ( . . ) Although all their colleagues considered them to be very organized, communicative, and proactive, and their teachers perceived them as very competent, Julia always stood out more for her high responsibility and teamwork spirit. Nowadays, Julia is a manager in a large, listed company, while Antonio chose a career in a smaller company ... (... ) Company $\mathrm{X}$, which is listed on the stock exchange, implemented this law and stipulated that when there are two people applying for a job, preference should be given to the more competent person. As she is more competent than Antonio, Julia was chosen for the position. 
Scenario 3 "female candidate less competent than male candidate": ( . . ) Although all their colleagues considered them to be very organized, communicative, and proactive, and their teachers perceived them as very competent, Antonio always stood out more for his high responsibility and teamwork spirit. Today, Antonio is a prominent manager in a large, listed company, while Julia chose a career in a smaller company ... ( . . . ) Company $X$, which is listed on the stock exchange, implemented this law and stipulated that, when there are two people applying for a job, the choice must be made by the Board of Directors. The Board, despite Antonio's recognized higher competence, did not consider him, and chose Julia for the position.

Scenario 4 "group membership": Julia and Antonio both work in the business world. Recently, Company $\mathrm{X}$ was recruiting for a senior management position and they both decided to apply. ( . . . ) Company $X$, which is listed on the stock exchange, implemented this law and stipulated that preference should be given to women. Because she is a woman, Julia was chosen for the position.

\subsection{Dependent Measures}

Attitudes towards the fairness of Law Number 62/2017 and the variable criterion in the model under study were measured by responding to three items accompanied by semantic differentiators presented on a 7-point Likert-type scale. The item defined by Taylor-Carter et al. (Taylor-Carter et al. 1995) assessed the fairness of the measure (unfairfair; harmful-beneficial; unacceptable-acceptable). The Santos (Santos 2004) items assessed the correctness of the measure (incorrect-correct) and the agreement with the measure (disagree-agree). A composite variable was then calculated for these items which returned a very good level of internal consistency $(\alpha=0.92)$.

For a general assessment of the law, 11 statements from Lorenzi-Cioldi and Buschini (Lorenzi-Cioldi and Buschini 2002) on AAMs in a business context were adapted on a 7-point Likert scale ( $1=$ strongly disagree to $7=$ strongly agree), e.g., "This is the best way to increase the number of women in the company". The scale attained an acceptable internal level of consistency $(\alpha=0.64)$ and one section, after preliminary analyses, served as an additional measure.

Predictor variables: We measured the prescriptive MBs according to an adapted version of the Preference for the Merit Principle Scale by Son Son Hing et al. (2011), incorporating 11 items answered on a 7-point Likert scale $(-3=$ strongly disagree to $3=$ agree, recoded from 1 to 7 for analysis), e.g., "At work, people's success should depend primarily on their performance" $(\alpha=0.83)$.

An adapted version of the Perceptions that Meritocracy Exists Scale by Son Hing et al. (Son Hing et al. 2011) with the identical items and scales as above, with the difference that the statements measure people's perceptions of how outcomes are distributed rather than how they should be distributed; for example, "At work, people's success depends primarily on their performance" $(\alpha=0.92)$.

\subsection{Additional and Socio-Demographic Questions}

The questionnaire asked participants for some socio-demographic information regarding their gender (which assumes the status of a moderating variable in the model under study), age, academic qualifications, profession, and the degree and year attended if they were students.

\section{Results}

\subsection{Preliminary Analyses}

We performed factor analysis by principal components (FAPC) with orthogonal rotation (varimax) on the items of Lorenzi-Cioldi and Buschini (2002); Taylor-Carter et al. (1995) and Santos (2004) with the purpose of determining the number and nature of the factors that best represent this set of items. The assumptions for conducting this analysis were verified $\left(\mathrm{KMO}=0.85 ; \chi^{2}(120)=2149.11, p<0.001\right)$, and we obtained four factors with 
eigenvalues $>1$, with a total explained variance of $64.79 \%$ (see Table 1 ). This means that the items cluster into four distinct groups that we designated as follows: attitudes towards the justice of the law; the consequences for the company; the merit of the female candidate; and the consequences for the out-group (i.e., for the men) ${ }^{1}$.

Table 1. Factor Analysis by Principal Components.

\begin{tabular}{|c|c|c|c|c|}
\hline \multirow[b]{2}{*}{ Items } & \multicolumn{4}{|c|}{ Factors } \\
\hline & $\begin{array}{l}\text { Attitudes towards } \\
\text { the Justice of Law }\end{array}$ & $\begin{array}{l}\text { Consequences for } \\
\text { the Company }\end{array}$ & $\begin{array}{l}\text { Merit of the Female } \\
\text { Candidate }\end{array}$ & $\begin{array}{l}\text { Consequences for } \\
\text { the Out-Group }\end{array}$ \\
\hline Totally unfair-Totally fair & 0.874 & & & \\
\hline $\begin{array}{l}\text { Totally harmful-Totally } \\
\text { beneficial }\end{array}$ & 0.896 & & & \\
\hline Totally wrong-Totally right & 0.911 & & & \\
\hline $\begin{array}{l}\text { Totally unacceptable-Totally } \\
\text { acceptable }\end{array}$ & 0.906 & & & \\
\hline $\begin{array}{l}\text { This law improves the } \\
\text { company's image }\end{array}$ & & 0.832 & & \\
\hline $\begin{array}{l}\text { This law adds benefit to the } \\
\text { company's image. }\end{array}$ & & 0.809 & & \\
\hline $\begin{array}{l}\text { This law improves working } \\
\text { conditions in the company. }\end{array}$ & & 0.624 & & \\
\hline $\begin{array}{l}\text { This law is beneficial to the } \\
\text { company from a financial } \\
\text { point of view. }\end{array}$ & & 0.673 & & \\
\hline $\begin{array}{l}\text { The candidate is qualified for } \\
\text { the position. }\end{array}$ & & & 0.876 & \\
\hline $\begin{array}{l}\text { The candidate is competent for } \\
\text { the position. }\end{array}$ & & & 0.877 & \\
\hline $\begin{array}{l}\text { This law compromises men's } \\
\text { access to management } \\
\text { positions. }\end{array}$ & & & & -0.863 \\
\hline $\begin{array}{l}\text { This law harms the competitor } \\
\text { (the man). }\end{array}$ & & & & -0.811 \\
\hline
\end{tabular}

To analyze the attitudes of the study participants, we carried out descriptive analysis and analysis of the correlations between the variables. According to Table 2, the "consequences for the company" variable positively correlates with "gender" $(r=0.15, p=0.02)$ and with "attitudes towards the justice of the law" $(r=0.36, p<0.001)$; the "merit of the female candidate" positively correlates with "prescriptive MB" $(r=0.23, p<0.001)$, with "attitudes towards the fairness of law" $(r=0.21, p=0.001)$ and with "consequences for the company" $(r=0.39, p<0.001)$; the "consequences for the out-group" variable negatively correlates with "attitudes towards the fairness of the law" $(r=-0.30, p<0.001)$, with "consequences for the company" $(r=-0.36, p<0.001)$ and with "merit of the applicant" $(r=-0.26, p<0.001)$. We encountered no other statistically significant correlations. 
Table 2. Descriptive Statistics and Correlation Coefficients.

\begin{tabular}{|c|c|c|c|c|c|c|c|c|}
\hline Variables & $M$ & $S D$ & 1 & 2 & 3 & 4 & 5 & 6 \\
\hline 1. Gender & - & - & & & & & & \\
\hline 2. Prescriptive MB & 5.60 & 0.88 & -0.04 & & & & & \\
\hline 3. Descriptive MB & 4.11 & 1.23 & -0.11 & 0.11 & & & & \\
\hline 4. Attitudes towards the justice of law & 4.62 & 1.68 & 0.04 & -0.001 & 0.08 & & & \\
\hline 5. Consequences for the company & 4.44 & 1.33 & $0.15^{*}$ & 0.09 & 0.11 & $0.36^{* *}$ & & \\
\hline 6. Merit of the female candidate & 5.30 & 1.17 & -0.05 & $0.23 * *$ & 0.08 & $0.21^{* *}$ & $0.39 * *$ & \\
\hline 7. Consequences for the out-group & 3.56 & 1.72 & -0.10 & -0.05 & -0.03 & $-0.30 * *$ & $-0.36^{* *}$ & $-0.26^{* *}$ \\
\hline
\end{tabular}

Note: $M=$ Mean; $S D=$ Standard Deviation. ${ }^{*} p<0.05 * * p 0.001$; Gender: $0=$ man; $1=$ woman. Spearman's correlation was used for the categorical variable "gender".

The mean of the attitudes towards the fairness of the law in the "equal competencies" condition was $4.38(S D=1.80)$; in the "woman more competent" condition, this stood at $5.13(S D=1.68)$; in the "less competent woman" condition, this was $4.32(S D=1.54)$; and finally, in the 'group membership' condition, $4.54(S D=1.59)$ was attained.

\subsection{Hypotheses Testing}

To assess the influence of the AAM type on attitudes towards the justice of Law Number 62/2017, we performed a one-way ANOVA between subjects. There was a statistically significant effect of the AAM type: $F_{(3,219)}=3.11, p=0.03, \eta^{2} p=0.04$. Applying Tukey's HSD test we encountered only marginal differences between the condition in which the female candidate is the most competent and the condition in which the female candidate is the least competent $(p=0.05)$. Although attitudes were significantly more favorable towards the fairness of the law in the condition where the female candidate was more competent compared to the condition where the female candidate was less competent than the male candidate, these results did not fully support the first hypothesis, which predicted that attitudes towards the fairness of Law Number 62/2017 would be more positive under the weak PT conditions when compared to the strong PT conditions.

In relation to gender, the women returned more positive attitudes towards the fairness of Law Number $62 / 2017(M=4.71, S D=1.62)$ when compared to the men $(M=4.50$, $S D=1.77)$. However, these differences are not statistically significant $\left(F_{(1,221)}=0.82\right.$ $p=0.37, \eta^{2} p=0.004$ ). Thus, the second hypothesis, which predicted gender differences in attitudes towards the fairness of the law, does not receive support from the data.

To test Hypotheses 3, 4 and 5, we made recourse to Macro PROCESS version 3.3 model 3 (Hayes 2017). As the predictor variable is multicategory, with four categories, we applied the Macro PROCESS option $\mathrm{mcx}=2$, which depicts the contrasts between the different groups using the "sequential coding" option of the coding system ${ }^{2}$.

Table 3 summarizes the expected moderating effect of the variables "descriptive MB" and "gender" on the relationship between "type of AAM" and "attitudes towards the justice of the law". The model did not attain significance $\left(F_{(15,207)}=1.12, p=0.33\right)$ and did not explain a significant proportion of the variance in attitudes towards the justice of the law $\left(R^{2}=0.08\right)$. Hypothesis 3 predicted that regardless of the PT status, the descriptive $\mathrm{MB}$ would lead to more negative attitudes towards the justice of the law. As set out in Table 3, the main effect of the descriptive MB on attitudes towards the justice of the law was negative and non-significant, which leads to Hypothesis 3 not being supported. 
Table 3. Testing the Moderating Effect of Descriptive MB and Gender on the Relationship Between the AAM Type and Attitudes Towards the Fairness of the Law.

\begin{tabular}{|c|c|c|c|}
\hline \multirow{2}{*}{ Variables } & \multirow[t]{2}{*}{ Model } & \multicolumn{2}{|c|}{ Attitudes towards the Justice of the Law } \\
\hline & & B & Standard Error \\
\hline Constant & & $4.38^{* *}$ & 0.22 \\
\hline X1 (A) & & $0.68^{*}$ & 0.31 \\
\hline $\mathrm{X} 2(\mathrm{~B})$ & & $-0.77 *$ & 0.34 \\
\hline X3 I & & 0.24 & 0.37 \\
\hline Descriptive MB (D) & & -0.005 & 0.18 \\
\hline Interaction effect $1\left(A^{*} \mathrm{D}\right)$ & & 0.38 & 0.25 \\
\hline Interaction effect $2\left(\mathrm{~B}^{*} \mathrm{D}\right)$ & & -0.30 & 0.30 \\
\hline Interaction effect $3\left(C^{*} D\right)$ & & -0.09 & 0.32 \\
\hline GendI(E) & & 0.29 & 0.44 \\
\hline Interaction effect $4\left(A^{*} E\right)$ & & -0.37 & 0.61 \\
\hline Interaction effect $5\left(B^{*} \mathrm{E}\right)$ & & 0.13 & 0.70 \\
\hline Interaction effect $6\left(C^{*} E\right)$ & & 0.65 & 0.76 \\
\hline Interaction effect $7\left(D^{*} \mathrm{E}\right)$ & & -0.23 & 0.35 \\
\hline Interaction effect $8\left(A^{*} D^{*} E\right)$ & & 0.36 & 0.49 \\
\hline Interaction effect $9\left(B^{*} D^{*} E\right)$ & & -0.18 & 0.64 \\
\hline \multirow[t]{3}{*}{ Interaction effect $10\left(C^{*} D^{*} E\right)$} & & 0.32 & 0.69 \\
\hline & $R^{2}=$ & 0.08 & \\
\hline & $F(15,207)=$ & 1.12 & \\
\hline
\end{tabular}

Note: ${ }^{*} p<0.05 ;{ }^{* *} p<0.001$; Gender: $0=$ man; $1=$ woman.

The model testifying to the moderating effect of "prescriptive MB" and "gender" on the relationship between "type of AAM" and "attitudes towards the justice of the law" also failed to attain significance $\left(F_{(15,207)}=1.39, p=0.15\right)$ and did not explain a significant proportion of the variance $\left(R^{2}=0.09\right.$; see Table 4$)$. Hypothesis 4 predicted that under strong PT conditions, the prescriptive MB would lead to more negative attitudes towards the justice of the law. However, this hypothesis was also not supported as the prescriptive MB did not significantly condition the relationship between the AAM type and the attitudes towards the justice of the law.

Table 4. Testing the Moderating Effect of Prescriptive MB and Gender on the Relationship between the AAM Type and Attitudes towards the Justice of the Law.

\begin{tabular}{|c|c|c|c|}
\hline \multirow{2}{*}{ Variables } & \multirow[t]{2}{*}{ Model } & \multicolumn{2}{|c|}{ Attitudes towards the Justice of the Law } \\
\hline & & B & Standard Error \\
\hline Constant & & $4.38 * * *$ & 0.22 \\
\hline X1 (A) & & $0.80^{* *}$ & 0.31 \\
\hline $\mathrm{X} 2(\mathrm{~B})$ & & $-0.82 * *$ & 0.32 \\
\hline X3 (C) & & 0.10 & 0.34 \\
\hline Prescriptive MB (D) & & -0.28 & 0.25 \\
\hline Interaction effect $1\left(A^{*} \mathrm{D}\right)$ & & 0.18 & 0.36 \\
\hline Interaction effect $2\left(B^{*} \mathrm{D}\right)$ & & -0.003 & 0.38 \\
\hline Interaction effect $3\left(C^{*} D\right)$ & & 0.20 & 0.38 \\
\hline GIer $(\mathrm{E})$ & & 0.26 & 0.44 \\
\hline Interaction effect $4\left(A^{*} E\right)$ & & -0.30 & 0.61 \\
\hline Interaction effect $5\left(B^{*} \mathrm{E}\right)$ & & 0.10 & 0.65 \\
\hline Interaction effect $6\left(C^{*} E\right)$ & & 0.57 & 0.70 \\
\hline Interaction effect $7\left(\mathrm{D}^{*} \mathrm{E}\right)$ & & 0.38 & 0.48 \\
\hline Interaction effect $8\left(A^{*} D^{*} E\right)$ & & 0.47 & 0.73 \\
\hline Interaction effect $9\left(B^{*} D^{*} E\right)$ & & $-1.79 *$ & 0.78 \\
\hline Interaction effect $10\left(C^{*} D^{*} E\right)$ & & $1.51 *$ & 0.77 \\
\hline & $R^{2}=$ & 0.09 & \\
\hline & $F(15,207)=$ & 1.39 & \\
\hline
\end{tabular}

Note: ${ }^{*} p=0.05 ;{ }^{* *} p<0.05 ;{ }^{* * *} p<0.001$; Gender: $0=$ man; $1=$ woman. 
Hypothesis 5 predicted that under strong PT conditions, the prescriptive MB would lead to more positive attitudes towards the justice of the law from the women when compared to those of the men. According to Table 3, there were no significant interaction effects between the descriptive MB, gender, and the AAM type. Thus, gender and the descriptive MB did not moderate the relationship between the AAM type and attitudes towards the justice of the law. According to Table 4, the interaction effect between X2, the prescriptive $\mathrm{MB}$, and gender was negative and significant $\left(B=-1.79, t_{(219)}=-2.30\right.$, $p=0.02$ ).

The interaction effect between $\mathrm{X} 3$, the prescriptive $\mathrm{MB}$, and gender was positive and marginally significant $\left(B=1.51, t_{(219)}=1.95, p=0.05\right)$. Nevertheless, gender and the AAM type did not moderate the relationship between the prescriptive $\mathrm{MB}$ and the attitudes towards the fairness of the law, although there were two significant interaction effects. In this sense, Hypothesis 5 was not fully supported.

\subsection{Additional Analysis}

Given that the "merit of the female candidate" variable reported a significant correlation with the attitudes towards the justice of the law (see Table 2), an additional mediation was carried out through the Macro PROCESS model 4 (see Figure 2). We proposed that the "merit of the female candidate" variable mediates the relationship between the AAM type and the attitudes towards the justice of the law. The variable "merit of the female candidate" returned good internal consistency $(\alpha=0.81)$.

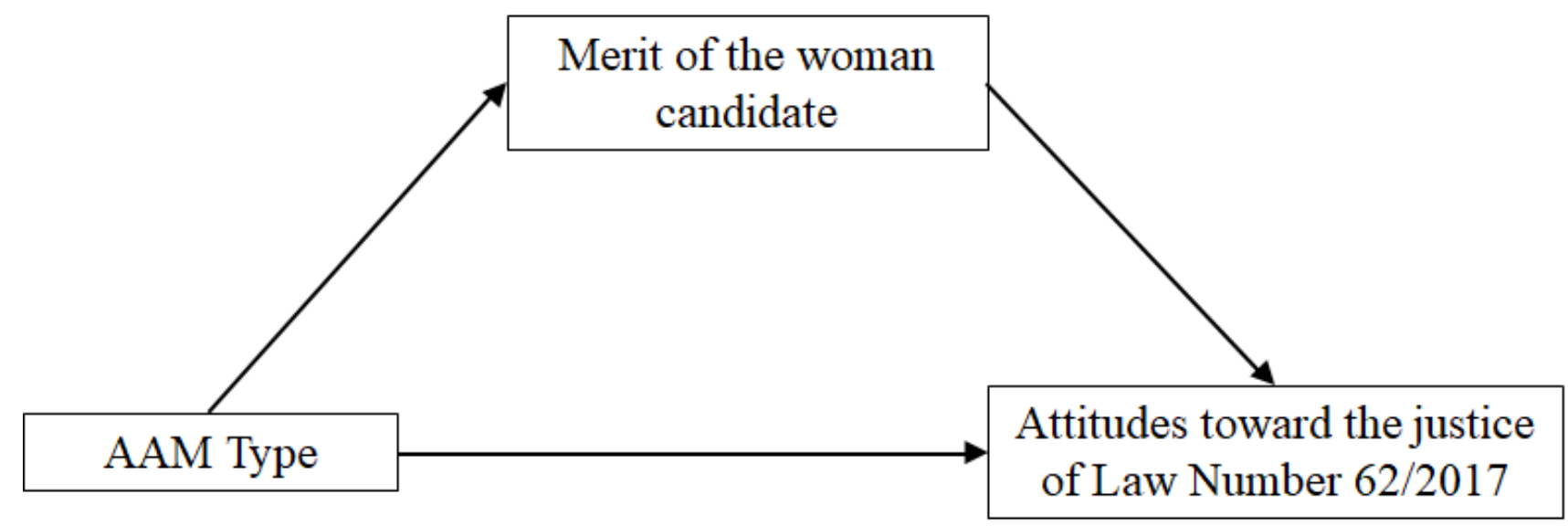

Figure 2. Additional mediation model. AAM - Affirmative Action Measure.

As the predictor variable is multi-categorical, with four categories, we applied the Macro PROCESS option mcx $=4$ to depict the contrasts between the different groups through the "effect coding" option in the coding system ${ }^{3}$. To estimate the indirect effects, we performed 10,000 bootstrap samples.

Based on the results presented in Table 5, the mediation model was significant $\left(F_{(4,218)}=4.74, p=0.001\right)$ and explains $8 \%\left(R^{2}=0.08\right)$ of the variance in attitudes towards the justice of the law, which means that the AAM type holds an effect on attitudes towards the justice of the law via the merit of the female candidate. 
Table 5. Testing the Mediating Effect of the Female Candidate's Merit on the Relationship between AAM Type and Attitudes towards the Justice of the Law.

\begin{tabular}{|c|c|c|c|c|c|}
\hline \multirow{2}{*}{\multicolumn{2}{|c|}{ Predictor Variables }} & \multicolumn{2}{|c|}{$\begin{array}{l}\text { Merit of the Female } \\
\text { Candidate }\end{array}$} & \multicolumn{2}{|c|}{$\begin{array}{c}\text { Attitudes towards the Justice } \\
\text { of the Law }\end{array}$} \\
\hline & & $B$ & $\begin{array}{l}\text { Standard } \\
\text { Error }\end{array}$ & $B$ & $\begin{array}{l}\text { Standard } \\
\text { Error }\end{array}$ \\
\hline \multicolumn{6}{|c|}{ Total Effect } \\
\hline \multicolumn{2}{|c|}{ Constant } & & & $4.59^{* *}$ & 0.11 \\
\hline \multicolumn{2}{|c|}{$\mathrm{X} 1$} & & & 0.54 * & 0.18 \\
\hline \multicolumn{2}{|c|}{$\mathrm{X} 2$} & & & -0.27 & 0.20 \\
\hline \multicolumn{2}{|c|}{$\mathrm{X} 3$} & & & -0.05 & 0.20 \\
\hline \multicolumn{6}{|c|}{ Direct Effect } \\
\hline \multicolumn{2}{|c|}{ Constant } & $5.27^{* *}$ & 0.08 & $3.02 * *$ & 0.53 \\
\hline \multicolumn{2}{|c|}{ X1 } & $0.39 *$ & 0.12 & $0.43 *$ & 0.18 \\
\hline \multicolumn{2}{|c|}{$\mathrm{X} 2$} & 0.10 & 0.14 & -0.30 & 0.20 \\
\hline \multicolumn{2}{|c|}{ X3 } & $-0.57^{* *}$ & 0.14 & 0.12 & 0.20 \\
\hline \multicolumn{2}{|c|}{ Merit of the female candidate } & & & 0.30 * & 0.10 \\
\hline \multicolumn{6}{|c|}{ Indirect Effect } \\
\hline & Coef. & $\begin{array}{l}\text { Standard } \\
\text { Error }\end{array}$ & \multicolumn{2}{|c|}{$95 \%$ Bootstrap CI } & \\
\hline $\mathrm{X} 1$ & 0.12 & 0.06 & 0.03 & 0.24 & \\
\hline $\mathrm{X} 2$ & 0.03 & 0.04 & -0.04 & 0.11 & \\
\hline $\mathrm{X} 3$ & -0.17 & 0.07 & -0.34 & -0.04 & \\
\hline
\end{tabular}

The X1 level of the variable "AAM type" had a positive and significant effect both on the applicant merit $\left(B=0.39, t_{(221)}=3.16, p=0.002\right)$ and on the attitudes towards the fairness of the law $\left(B=0.43, t_{(221)}=2.32, p=0.02\right)$. Similarly, the effect of the female candidate merit on attitudes towards the fairness of the law was positive and significant $\left(B=0.30, t_{(221)}=3.05, p=0.003\right)$. The indirect effect of $X 1$ on attitudes towards the fairness of the law was positive and significant $(B=0.12$, Boot $95 \%$ IC $=0.03 ; 0.24)$, with partial mediation occurring. Furthermore, level X3 generated a negative and significant effect on the merit of the female candidate variable $\left(B=-0.57, t_{(221)}=-4.22, p<0.001\right)$. In turn, the effect of $\mathrm{X} 3$ on attitudes towards the fairness of the law was positive but not significant $\left(B=0.12, t_{(221)}=0.57, p=0.57\right)$, with complete mediation occurring and the indirect effect being negative and significant $(B=-0.17$, Boot 95\% IC $=-0.34 ;-0.04)$.

\section{Discussion}

This study sought to grasp the tolerance of individuals towards the justice of Law Number 62/2017 and to analyze the influence of the MB type, the AAM type, and gender on individual attitudes towards the justice of Law Number 62/2017 and correspondingly design and test a research model (see Figure 1). Overall, participant attitudes towards the justice of the law were positive and the results indicated a significant effect of the AAM type on attitudes towards the perceived fairness of the law.

Regarding the first hypothesis, we expected that the attitudes towards the justice of Law Number 62/2017 would be more positive in the weak PT conditions compared to the strong PT conditions. The data pointed to a significant effect of the AAM type on attitudes towards the justice of Law Number 62/2017. However, only marginal differences were found between the condition in which the female candidate is more competent and the condition in which that candidate is less competent. Thus, these results did not fully support hypothesis 1.

A possible explanation arises from the justification applied to the implementation of Law Number 62/2017. In the experimental scenarios presented to the participants, we stated that this law aimed at increasing the presence of women in the management 
and supervisory bodies of companies, as indeed mentioned in the legislation. However, according to previous research (Santos et al. 2013; Kravitz 1995), attitudes are more positive when AAMs are justified on the grounds that they increase diversity but are more negative when the argument highlights how the target group is numerically under-represented (Harrison et al. 2006). The justification provided may not have been clear to the participants and may have been interpreted in various ways, both negative and positive, thus masking the differences expected between the types of AAM.

Regarding the second hypothesis, we expected that the female participants would express more positive attitudes towards the justice of the law compared to that of their male peers. However, the results obtained do not support this hypothesis. Although the women did on average show more positive attitudes than men towards the fairness of Law Number 62/2017, these differences were not statistically significant. A study by Krings et al. (Krings et al. 2007) found that women showed more positive attitudes towards AAMs than men. However, this relationship was mediated entirely by symbolic prejudice. These results suggest that the relationship between gender and attitudes towards the justice of the law may have been influenced by other factors that fall beyond the scope of this research study (e.g., symbolic prejudice and sexism).

In the third hypothesis, we forecasted that the descriptive MB would lead to more negative attitudes towards the fairness of the law regardless of the type of AAM, which did not prove to be the case as the main effect of the descriptive MB on attitudes towards the justice of this law did not obtain significance. Hypothesis 4 predicted that under strong PT conditions, when compared to weak PT conditions, the prescriptive MB would lead to more negative attitudes towards this gender equality legislation. This hypothesis was also not supported by the data.

The descriptive MB did not significantly condition the relationship between the AAM type and the attitudes towards the justice of this law. Finally, Hypothesis 5 expected that under strong PT conditions, the prescriptive $\mathrm{MB}$, when compared to the descriptive $\mathrm{MB}$, would lead to more positive attitudes towards the justice of the law among women in comparison to men. This hypothesis also did not gain support. Thus, gender and the MB type did not moderate the relationship between the type of AAM and the attitudes towards the justice of Law Number 62/2017.

Contrary to the results obtained by Son Hing et al. (Son Hing et al. 2011), neither the prescriptive nor the descriptive MB displayed any relationship with attitudes towards the fairness of pro-gender equality legislation. Previous research studies have also reported no significant relationship between the prescriptive MB and the support for weak PT measures (Aberson and Haag 2003; Bobocel et al. 1998). These results suggest that selection among equally or comparably qualified candidates may not violate the concerns prevailing around distributive justice (Aberson 2007). Additionally, some authors argue that conceptualizing the AAM selection process solely based on group membership (strong PT), without considering merit, is unrealistic and unlikely to happen in real life, which may influence reactions to the AAMs. The application of scenarios perceived as unrealistic in some of the experimental conditions applied in this research may have influenced attitudes towards the justice of Law Number 62/2017 (e.g., Crosby and Clayton 2001; Crosby et al. 2003; Kravitz 1995).

Given that the support for MBs displayed no relationship with the variables under study, we therefore conducted some additional statistical analyses to assess whether the merit of the female candidate would have any effect on attitudes towards the fairness of Law Number 62/2017. This tested the mediating effect of the merit of the female candidates on the relationship between the AAM type and the attitudes towards the fairness of Law Number 62/2017. Here, we expected the merits of the female candidates to mediate the relationship between the AAM type and the attitudes towards the fairness of Law Number $62 / 2017$. According to the results obtained, the merit of the female candidate partially mediates the relationship between the X1 level of the AAM type variable (which contrasts the conditions of "most competent female candidate" with "equality of competences") 
and the attitudes towards the fairness of this law. Hence, the attitudes towards the law's justice become more positive under the condition stipulating the greater competence of the female candidate when compared to the condition of equal competences between the female and the male candidates. However, the merit of the female candidate also influences this relationship under the condition in which the female candidate is more competent, generating a more positive assessment of her merit, which in turn leads to more positive attitudes towards the respective law's justice.

Additionally, the merit of the female candidate fully mediates the relationship between the X3 level of the AAM type variable (which contrasts the "group membership" condition with the "equal competences" condition) and the attitudes towards justice. In the "group membership" condition, the assessment of the female candidate's merit was more negative in comparison to the "equal competences" condition and with more negative assessments of merit leading to less positive attitudes towards the justice of Law Number 62/2017. These results align with the findings of other studies (e.g., Davey et al. 1999; Harrison et al. 2006; Kravitz 1995; Krings et al. 2007; Son Hing et al. 2002; Taillandier-Schmitt and Maisonneuve 2019) and convey how the reactions to AAMs are more negative when the choice is based on group membership and more positive when based on merit, thus highlighting the importance attributed both to merit and to violations of the merit principle.

\section{Conclusions}

Reactions to AAMs have been quite controversial and dependent on several factors. Despite the numerous studies on this theme, to our knowledge there have been no studies evaluating the reactions towards the justice of Law Number 62/2017. The research results obtained here demonstrate how attitudes towards the justice of this law are, in general, positive and that merit plays an important role in such reactions. The merit of the female candidate shaped the relationship between the AAM type and the reactions towards the justice of the law, with the assessment of the female candidate's merit and attitudes towards the law's fairness becoming more positive under weak PT scenarios. The perception of merit held about the candidates thus appears to constitute a crucial requirement in the assessments made of AAMs (Son Hing et al. 2002) and furthermore emerges as important in the assessments made of Law Number 62/2017, thus conveying how merit reflects a normative facet.

Indeed, it then becomes particularly important to reflect on the question of "How does one assess a person's merit?" According to Crosby and Clayton (Crosby and Clayton 2001), there is no one measure of merit that is totally objective and rigorous; therefore, it is necessary to be aware of biases that favor dominant groups, such as, for example, the subjective evaluations of someone's performance (Crosby and Clayton 2001; Son Hing et al. 2002).

For example, the characteristics required to serve as members of parliament (Santos and Amâncio 2010b, 2012; Santos 2004) or hold managerial positions (Mónico et al. 2019; Silva 2020) reflect personality traits. Thus, the assessment of personality traits is subjective and not very rigorous, which emphasizes the difficulty of measuring, in any objective and consensual way, the merit of a person.

Regarding the limitations of this study, we would highlight how the sample was unbalanced. More than half were women and most of the participants were highly educated and were university students, with a correspondingly low mean age $(M=27.20)$. Thus, the sample is not representative of the population. Although we attempted getting university students close to entering the job market, that is not a replacement for actual experience, especially regarding the decisions underlying job promotions. We speculate that a sample composed of non-student participants could be less favorable to AAMs, precisely because these scenarios would be interpreted in connection with personal experiences. At the same time, opposition to AAMs could result from age/generational aspects, as younger cohorts are more aware in general regarding social justice concerns (Parker et al. 2020). In a way, having a sample that is more tabula rasa allows the testing of the scenarios 
themselves, ensuring internal validity outside the participant's own history, which is important as a first step. On the other hand, external validity is also quite important, as the AAMs are not proposed and enforced in a societal vacuum. Thus, future studies should continue addressing this research question with participants already in the job market, while statistically controlling for their age.

In addition, we did not measure variables such as sexism (e.g., Harrison et al. 2006; Kravitz 1995; Son Hing et al. 2011) and perceived discrimination (e.g., Aberson 2007; Harrison et al. 2006; Kravitz and Klineberg 2000; Son Hing et al. 2002), which other research has shown to interrelate with the participant reactions to AAMs and which, in this research, may also have influenced the reactions towards the fairness of the law.

Despite these limitations, this research makes some theoretical contributions, including portraying the fact that merit seems to play a relevant role in attitudes towards the justice of the law, with weak PT conditions tending to foster more positive attitudes. These results are in line with other research findings (e.g., Davey et al. 1999; Harrison et al. 2006; Krings et al. 2007) and highlight the importance attached to merit when assessing the fairness of AAMs. However, it becomes especially difficult to measure merit when the characteristics associated with it reflect personality traits (Santos 2004; Santos and Amâncio 2010b, 2012; Mónico et al. 2019; Silva 2020).

There is a need for further research on the influence of gender on attitudes towards AAMs as this relationship does not emerge as being as linear as the literature otherwise reports and may be impacted by other factors, such as the perceived discrimination that members of the target group may experience. Additionally, it is also important to continue researching the consequences of the MB type on attitudes towards AAMs as the descriptive MBs still remain understudied, and weak PT measures do not seem to violate the principles of the prescriptive MBs. Finally, there is every relevance in better understanding the role of gender in the relationship between MBs and attitudes towards AAMs.

In addition to the theoretical contributions, the contributions to organizational practice deserve highlighting. The organizations planning to implement AAMs such as Law Number $62 / 2017$ should pay attention to several aspects. Taking into consideration the results obtained in this research, the organizations should opt to adopt softer measures with more transparent selection processes, as well as justifying the respective need. This justification should emphasize the need to redress past discrimination and/or the practical value of diversity in working teams resulting from successful AAMs. Communicating these justifications should address both employees and potential candidates, which together should lessen concerns about the fairness of the measure (Harrison et al. 2006). Finally, given the centrality of merit, organizations should also emphasize that the competences of potential candidates will be taken into consideration and not only their group memberships (Faniko et al. 2012). In this way, the different opinions on these measures may be appeased and thereby ease the implementation of AAMs.

In conclusion, the reactions to Law Number 62/2017 were generally positive, which demonstrates how people are broadly receptive to such legislation, and there is already some awareness about the inequalities women suffer in the workplace.

Author Contributions: Conceptualization, V.S., M.H.S. and M.R.; methodology, V.S.; software: V.S., M.H.S. and M.R.; validation: M.H.S. and M.R.; formal analysis, V.S. and M.R.; investigation, V.S.; resources, M.H.S. and M.R.; data curation, V.S.; writing-original draft preparation, V.S., M.H.S. and M.R.; writing-review and editing, V.S., M.H.S. and M.R.; supervision, M.H.S. and M.R.; funding acquisition, V.S.; All authors have read and agreed to the published version of the manuscript.

Funding: This research was funded by the FCT-Fundação para a Ciência e Tecnologia, I.P., under the Transitory Norm-DL 57/2016/CP 1359/CT0023 and DL 57/2016/CP1359/CT0027-provided to the second and third author, respectively.

Institutional Review Board Statement: The study was conducted according to the guidelines of the Declaration of Helsinki, and approved by the Ethics Committee of Iscte-Instituto Universitário de Lisboa, Portugal, at 9 March 2020. 
Informed Consent Statement: Informed consent was obtained from all study participants.

Data Availability Statement: The original data collected and used in this paper, as well as the output of analyses conducted can be found here: https: / / osf.io/9asnj/ ?view_only=2d3556cf122f475b8e5 2da1ccf53c7ed.

Acknowledgments: The authors would like to thank the FCT and all the participants in our study.

Conflicts of Interest: The authors declare no conflict of interest.

\section{Notes}

1 Data from four items were excluded due to low correlation loading in multiple factors.

2 In this sense, $\mathrm{X} 1$ contrasts the condition "female candidate more competent than male candidate" with the condition "female candidate less competent than the male candidate" and with the condition "group membership" keeping the condition "equality of competencies between the female candidate and the male candidate" as the reference value; X2 contrasts the strong PT conditions ("female candidate less competent" with "group membership"), keeping the weak PT condition as the reference value; and finally, X3 analyzes the condition "group membership" while retaining the other three conditions as the reference value.

3 Hence, X1 contrasts the weak PT conditions (i.e., "female candidate more competent than male candidate" with "equality of competencies between female candidate and male candidate"), keeping the strong PT conditions ("female candidate less competent than male candidate" and "group membership") as a reference value; X2 contrasts the condition "less competent female candidate" with the condition "equal competences between the female candidate and the male candidate", retaining the other two conditions as the reference values before X3 lastly contrasts the condition "group membership" with the condition "equal competences between the female candidate and the male candidate" while keeping the other two as the reference values.

\section{References}

Aberson, Christopher L. 2007. Diversity, Merit, Fairness, and Discrimination Beliefs as Predictors of Support for Affirmative-Action Policy Actions. Journal of Applied Social Psychology 37: 2451-74. [CrossRef]

Aberson, Christopher L., and Sarah C. Haag. 2003. Beliefs about Affirmative Action and Diversity and Their Relationship to Support for Hiring Policies. Analyses of Social Issues and Public Policy 3: 121-38. [CrossRef]

Acker, Joan. 2009. From Glass Ceiling to Inequality Regimes. Sociologie Du Travail 51: 199-217. [CrossRef]

Amâncio, Lígia, and Rita B. Correia. 2019. Em Busca Da Igualdade: Perceção de Justiça e Divisão Do Trabalho Doméstico-Mudanças e Continuidades. Sociologia, Problemas e Praticas 90: 77-94. [CrossRef]

Amâncio, Lígia, and João Manuel Oliveira. 2006. Men as Individuals, Women as a Sexed Category: Implications of Symbolic Asymmetry for Feminist Practice and Feminist Psychology. Feminism and Psychology 16: 35-43. [CrossRef]

Amâncio, Lígia, and Maria Helena Santos. 2021. Gender Equality and Modernity in Portugal. An Analysis on the Obstacles to Gender Equality in Highly Qualified Professions. Social Sciences 10: 162. [CrossRef]

Batruch, Anatolia, Frédérique Autin, and Fabrizio Butera. 2019. The Paradoxical Role of Meritocratic Selection in the Perpetuation of Social Inequalities at School. In The Social Psychology of Inequality. Basingstoke: Springer Nature, pp. 141-57. [CrossRef]

Bobocel, D. Ramona, Leanne S. Son Hing, Liane M. Davey, David J. Stanley, and Mark P. Zanna. 1998. Justice-Based Opposition to Social Policies: Is It Genuine? " Journal of Personality and Social Psychology 75: 653-69. [CrossRef]

Casaca, Sara Falcão, and Johanne Lortie. 2018. Género e Mudança Organizacional. Turim: Centro Internacional de Formação da Organização Internacional do Trabalho.

Castaño, Ana M., Yolanda Fontanil, and Antonio L. García-Izquierdo. 2019. 'Why Can't I Become a Manager?'-A Systematic Review of Gender Stereotypes and Organizational Discrimination. International Journal of Environmental Research and Public Health 16: 1813. [CrossRef]

Chou, Tzy-Yuan, Seng-Cho T. Chou, James J. Jiang, and Gary Klein. 2013. The Organizational Citizenship Behavior of IS Personnel: Does Organizational Justice Matter? Information and Management 50: 105-11. [CrossRef]

Commission for Citizenship and Gender Equality. 2015. Igualdade de Género em Portugal 2014. Available online: https://www.cig. gov.pt/wp-content/uploads/2016/03/Igualdade-de-Género-em-Portugal-2014.pdf (accessed on 1 October 2021).

Crosby, Faye J., and Susan Clayton. 2001. Affirmative Action: Psychological Contributions to Policy. Analyses of Social Issues and Public Policy 1: 71-87. [CrossRef]

Crosby, Faye J., Aarti Iyer, Susan Clayton, and Roberta A. Downing. 2003. Affirmative Action: Psychological Data and the Policy Debates. American Psychologist 58: 93-115. [CrossRef] [PubMed]

Crosby, Faye J., Aarti Iyer, and Sirinda Sincharoen. 2006. Understanding Affirmative Action. Annual Review of Psychology 57: 585-611. [CrossRef] [PubMed]

Davey, Liane M., D. Ramona Bobocel, Leanne S. Son Hing, and Mark P. Zanna. 1999. Preference for the Merit Pinciple Scale: An Individual Difference Measure of Distributive Justice Preferences. Social Justice Research 12: 223-40. [CrossRef]

Faniko, Klea, Fabio Lorenzi-Cioldi, and Fabrice Buschini. 2010. Education, Meritocracy and Opinions toward Affirmative Action Targeted at Women in Albania. SEER Journal for Labour and Social Affairs in Eastern Europe 13: 565-77. [CrossRef] 
Faniko, Klea, Fabio Lorenzi-Cioldi, Fabrice Buschini, and Armand Chatard. 2012. The Influence of Education on Attitudes toward Affirmative Action: The Role of the Policy's Strength. Journal of Applied Social Psychology 42: 387-413. [CrossRef]

Garcia, Donna M., Serge Desmarais, Nyla R. Branscombe, and Stephanie S. Gee. 2005. Opposition to Redistributive Employment Policies for Women: The Role of Policy Experience and Group Interest. British Journal of Social Psychology 44: 583-602. [CrossRef] [PubMed]

Harrison, David A., David A. Kravitz, David M. Mayer, Lisa M. Leslie, and Dalit Lev-Arey. 2006. Understanding Attitudes toward Affirmative Action Programs in Employment: Summary and Meta-Analysis of 35 Years of Research. Journal of Applied Psychology 91: 1013-36. [CrossRef]

Hauser, David J., Phoebe C. Ellsworth, and Richard Gonzalez. 2018. Are Manipulation Checks Necessary? Frontiers in Psychology 9: 1-10. [CrossRef] [PubMed]

Hayes, Andrew F. 2017. Introduction to Mediation, Moderation, and Conditional Process Analysis: A Regression-Based Approach, 2nd ed. New York: Guilford Publications.

Jost, John T., and Orsolya Hunyady. 2005. Antecedents and Consequences of System-Justifying Ideologies. Current Directions in Psychological Science 14: 260-65. [CrossRef]

Kravitz, David A. 1995. Attitudes toward Affirmative Action Plans Directed at Blacks: Effects of Plan and Individual Differences. Journal of Applied Social Psychology 25: 2192-220. [CrossRef]

Kravitz, David A., and Judith Platania. 1993. Attitudes and Beliefs about Affirmative Action: Effects of Target and of Respondent Sex and Ethnicity. Journal of Applied Psychology 78: 928-38. [CrossRef]

Kravitz, David A., Tiffany M. Bludau, and Stephen L. Klineberg. 2008. The Impact of Anticipated Consequences, Respondent Group, and Strength of Affirmative Action Plan on Affirmative Action Attitudes. Group and Organization Management 33: 361-91. [CrossRef]

Kravitz, David A., and Stephen L. Klineberg. 2000. Reactions to Two Versions of Affirmative Action among Whites, Blacks, and Hispanics. Journal of Applied Psychology 85: 597-611. [CrossRef] [PubMed]

Krings, Franciska, Franziska Tschan, and Sophie Bettex. 2007. Determinants of Attitudes toward Affirmative Action in a Swiss Sample. Journal of Business and Psychology 21: 585-611. [CrossRef]

Lee, Roland Arthur. 1999. The Evolution of Affirmative Action. Public Personnel Management 28: 393-409. [CrossRef]

Law Number 62/2017 of 1 August. 2017. Serie I. Lisboa: Diário da República n. ${ }^{o}$ 147/2017. Available online: https:/ /dre.pt/home/- / dre/107791612/details / maximized (accessed on 1 October 2021).

Organic Law number 1/2019 of 29 March. 2019. Available online: https://dre.pt/home/-/dre/121712770/details/maximized (accessed on 1 October 2021).

Lorenzi-Cioldi, Fabio, and Fabrice Buschini. 2002. Carrière Au Masculin et Carrières Au Féminin. In 6ème Conférence Internationale Sur Les Représentations Sociales. Scotland: Stirling.

Madeira, Ana Filipa, Rui Costa-Lopes, John F. Dovidio, Gonçalo Freitas, and Mafalda F. Mascarenhas. 2019. Primes and Consequences: A Systematic Review of Meritocracy in Intergroup Relations. Frontiers in Psychology 10: 1-21. [CrossRef]

Major, Brenda, and Cheryl R. Kaiser. 2017. Ideology and the Maintenance of Group Inequality. Group Processes and Intergroup Relations 20: 1-11. [CrossRef]

Mijs, Jonathan J. B. 2016. The Unfulfillable Promise of Meritocracy: Three Lessons and Their Implications for Justice in Education. Social Justice Research 29: 14-34. [CrossRef]

Mónico, Lisete, Leonor Pais, Inês M. Pratas, and Nuno R. Santos. 2019. Como é o Chefe Ideal? Um Estudo Sobre a Sua Representação Social Em Portugueses. Psicologia 33: 1-18. [CrossRef]

Morgenroth, Thekla, and Michelle K. Ryan. 2018. Quotas and Affirmative Action: Understanding Group-Based Outcomes and Attitudes. Social and Personality Psychology Compass 12: 1-14. [CrossRef]

Moscoso, Silvia, Antonio L. García-Izquierdo, and María Bastida. 2012. A Mediation Model of Individual Differences in Attitudes toward Affirmative Actions for Women. Psychological Reports 110: 764-80. [CrossRef]

Parker, Kim, Graf Nikki, and Igielnik Ruth. 2020. Generation Z Looks a lot Like Millennials on Key Social and Political Issues. May 30 Pew Research Center's Social \& Demographic Trends Project. Available online: https:/ / www.pewresearch.org/social-trends/2019/0 1/17/generation-z-looks-a-lot-like-millennials-on-key-social-and-political-issues/ (accessed on 7 October 2021).

Pereira, Jamille Barbosa Cavalcanti, Ana Paula de Almeida, Juliana Garcia Cordeiro, Marcia Macedo Junqueira Cestari, Leandro Queiroz Alencar, and Ademar Luiz Mendonça Neto. 2012. A Perceção de Justiça Organizacional Distributiva Diante de Ações Que Oferecem Recursos e Oportunidades à Diversidade. Revista Eletrônica de Ciência Aministrativa 11: 143-61. [CrossRef]

Rai, Alka, Piyali Ghosh, and Tanusree Dutta. 2019. Total Rewards to Enhance Employees' Intention to Stay: Does Perception of Justice Play Any Role? Evidence-Based HRM 7: 262-80. [CrossRef]

Santos, Maria Helena. 2004. Género e Política: Uma Análise Psicossociológica Das Reacções Às Acções Positivas (Dissertação de Mestrado). Lisboa: Instituto Universitário de Lisboa (ISCTE-IUL).

Santos, Maria Helena, and Lígia Amâncio. 2010a. A (in)Justiça Relativa Da Acção Positiva - A Influência Do Género Na Controvérsia Sobre as Quotas Baseadas No Sexo. Análise Psicológica 28: 43-57. [CrossRef]

Santos, Maria Helena, and Lígia Amâncio. 2010b. A Competência Política, a Desigualdade de Género e as Medidas de Acção Positiva: Uma Questão ‘Natural' Ou de 'Competência'? Psicologia 24: 117-40. [CrossRef] 
Santos, Maria Helena, and Lígia Amâncio. 2012. Resistências à Igualdade de Género Na Política. Ex Aequo 25: 45-58.

Santos, Maria Helena, Lígia Amâncio, and Hélder Alves. 2013. Gender and Politics: The Relevance of Gender on Judgements about the Merit of Candidates and the Fairness of Quotas. Portuguese Journal of Social Science 12: 133-49. [CrossRef]

Silva, Virgínia. 2020. Reações a Medidas de Ação Positiva: O Género e o Mérito Em Empresas Abrangidas Pela Lei n..$^{\circ}$ 62/2017. Iscte: Instituto Universitário de Lisboa.

Son Hing, Leanne S., D. Ramona Bobocel, and Mark P. Zanna. 2002. Meritocracy and Opposition to Affirmative Action: Making Concessions in the Face of Discrimination. Journal of Personality and Social Psychology 83: 493-509. [CrossRef] [PubMed]

Son Hing, Leanne S., D. Ramona Bobocel, Mark P. Zanna, Donna M. Garcia, Stephanie S. Gee, and Katie Orazietti. 2011. The Merit of Meritocracy. Journal of Personality and Social Psychology 101: 433-50. [CrossRef] [PubMed]

Taillandier-Schmitt, Anne, and Christelle Maisonneuve. 2019. French Attitudes toward Affirmative Action Programs and Their Beneficiaries. Swiss Journal of Psychology 78: 37-49. [CrossRef]

Taylor-Carter, Mary Anne, Dennis Doverspike, and Ralph Alexander. 1995. Message Effects on the Perceptions of the Fairness of Gender-Based Affirmative Action: A Cognitive Response Theory-Based Analysis. Social Justice Research 8: 285-303. [CrossRef] 